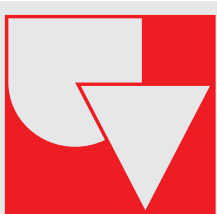

Universidad del Valle

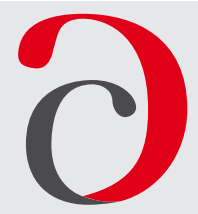

Cuadernos de Administración

\title{
Circular economy and reducing consumption from a decolonial approach
}

\author{
Economía circular y reducción del consumo desde el enfoque decolonial
}

\section{${ }^{1}$ Omar Cabrales Salazar (D)}

Professor, Faculty of Education and Humanities, Universidad Militar Nueva Granada, Bogotá D.C. Colombia e-mail: omar.cabrales@unimilitar.edu.co

\section{${ }^{2}$ Florentino Márquez Vargas $\mathbb{D}$}

Professor, Faculty of Medicine, Universidad Militar Nueva Granada, Bogotá, Colombia

e-mail: florentino.marquez@unimilitar.edu.co

\section{${ }^{3}$ Edgar Javier Garzón Pascagaza DD}

Professor, Faculty of Education and Humanities, Universidad Militar Nueva Granada, Bogotá D.C. Colombia e-mail: edgar.garzon@unimilitar.edu.co

\section{Abstract}

Reflection paper, which from the decolonial perspective, understood as the detachment of the westerners' epistemologies, raises the alternative proposal of the Circular Economy (CE) and reducing consumption, in which compensation is claimed for the environmental damage generated by consumerism and the exploitation of natural resources in the past 30 years. The CE assumes the cyclical structure of nature, to generate a model for the use of ecosystem resources and to bring industrial production to the bare minimum by including the reuse of inputs that, due to their characteristics, should not return to the environment. The methodology used consisted of a conceptual review based on 30 documents published between 1990 and 2020. For the bibliographic search, academic databases were used. In addition, for the co-occurrence relationships by semantic link, the BibExcel software was used and, for the visualization of semantic communities, the Gephi program. It is concluded that strategies must be designed to strengthen the alternative proposal to reduce consumption, within the framework of globalized markets embedded in the guidelines of a circular economy.

Keywords: Decoloniality; Consumerism; Circular economy; Sustainability; Recycling 8R.

1 Economy, Universidad Militar Nueva Granada, Colombia, Doctor in Social and Human Sciences, Pontificia Universidad Javeriana, Colombia.

2 Bachelor of Philosophy and Letters, Universidad Javeriana, Colombia, Doctor in Bioethics, Universidad Militar Nueva Granada, Colombia.

3 Bachelor of Philosophy, Universidad Minuto de Dios, Colombia, Doctor (c) Education, Universidad Santo Tomás, Colombia. 


\section{Resumen}

Artículo de reflexión que, desde la perspectiva decolonial, entendida como el desprendimiento de las epistemologías occidentales, plantea la propuesta alternativa de la Economía Circular (EC) y la reducción del consumo, en la que se reclama la compensación ante el daño ambiental generado por el consumismo y la explotación de los recursos naturales en los últimos 30 años. La economía circular asume la estructura cíclica de la naturaleza, para generar un modelo de aprovechamiento de recursos ecosistémicos, para llevar la producción industrial al mínimo indispensable, incluyendo la reutilización de los insumos que por sus características no deben retornar al medio ambiente. La metodología utilizada consistió en una revisión conceptual a partir de 30 documentos publicados entre 1990 y 2020. Para la búsqueda bibliográfica se utilizaron bases de datos académicas, además, para las relaciones de co-ocurrencia por vínculo semántico se utilizó el software BibExcel, y para la visualización de las comunidades semánticas el programa Gephi. Se concluye que deben diseñarse estrategias para fortalecer la propuesta alternativa de reducción del consumo, en el marco de los mercados globalizados, dentro de los lineamientos de una economía circular.

Palabras Clave: Decolonialidad; Consumismo; Economía circular; Sostenibilidad; Reciclaje 8R.

\section{Introduction}

In the last twenty years, academic debates in Latin America have focused on questioning the "neoliberal approach", evidencing that it is an exogenous model of mandatory application for developing economies, and which has had negative consequences on the environment for conserving extractive models as their source of foreign exchange. It is argued that this approach generates an unrestricted opening to developed economies: it cuts public spending, eliminates social subsidies and privatizes state companies, which established a favorable climate to achieve unlimited enrichment of large multinationals and increased inequality and social security, poverty in former Third World countries (Piketty, 2014; Harvey, 2008; Bernstein, 1973).

Based on this context, new thought models have been proposed that seek to vindicate other ideals of progress disconnected from neoclassical economic theory (Cabrales and Márquez, 2016). Ones which build benchmarks that enable creating more native epistemological models, and properly address issues of poverty and environmental damage in the planet's most neglected regions. In this vein, we find decolonial thinking, which "deals with an epistemic positionality related to specific colonized/colonizer power relations" (p.38) as asserted by Díaz (2017). In the same respect, other authors point out his efforts toward understanding the relationships inherent to colonialism and epistemically and politically rethinking the structures of domination and control that are still present in those societies influenced by Western thought, which are evidenced in backwardness (Mignolo, 2005; CastroGomez, 2007; Quijano, 2007; Escobar, 2005b), social and economic inequality for more than thirty years.

Following this train of thought, decoloniality represents for Latin America the detachment of the Western thought and bases of power, the disengagement of the logic of modernity, and an epistemic alternative that enables reflecting beyond the rationalist theoretical frameworks; those that excluded the indigenous sensibility and ancestral knowledge. In this vision, there are the "new" Latin American social movements (Bajoit, Houtart, and Duterme, 2009, Quijano, 2000), which are better coordinated with the cultural identity of the peoples of the South, from the South American region, and with more participatory forms of organization, among which the concept of CE stands out. As Quijano (2007) said, "The concept of decoloniality accounts for the thinking that critically analyzes the matrix of colonial power that, in global capitalism, persists under totalizing forms of knowledge that reaffirm the dominator-dominated binomial" (p. 173).

This occurs while in the world, especially at the beginning of the 21st century, economic discussions with a global perspective revolve around three critical pillars: economic growth, social equality, and environmental impact. Under such framework, there has been an attempt at proposing solutions for poverty reduction and wealth redistribution based on the sustainable development formula, a concept created by the proposals of the 1992 Earth Summit and later ratified by the Millennium Goals and Sustainable Development Goals (UNDP, 2015) which, despite efforts, remain still as proposals created in terms of the axes of power that 
fail to rethink humanity's future beyond indefinite economic growth. These issues have also become a structural part of decolonial thinking, since they retain an anthropocentric view and the exploitation conditions of developing countries.

Consequently, the decolonial approach has been progressively structured in Latin America to the extent that it is currently considered a theoretical tool that provides important conceptual instruments to assess other alternative development models that allow the regeneration of ecosystems. Also, to give way to the articulation of proposals tending to change the epistemological approach from which development or the ideals of progress are built, with ecological perspectives that diminish the exaggerated extraction of resources and waste such as the $\mathrm{CE}$, it has received considerable attention worldwide. It has been so because it offers an opening to improve and promote sustainable production and consumption through new models based on moderate growth and limitless resources. In the same way, to judge foreign economic theories, particularly the neoclassical ones such as those that, based on their perspective of productivism, encouraged and enabled the exploitation and appropriation of the planet's natural resources by hegemonic countries or those that generate phenomena such as exacerbated consumerism (Martínez, Henríquez, and Freire (2019).

Regarding this phenomenon, the alternative approach of CE arises, which reflects on the need to implement an evolutionary transition toward a new stage of Western society. This phase acting as a scenario that from the paradigm of development focused on consumption and waste give way to other models focused more on the survival of natural ecosystems and, also, on the equilibrium with the resources offered by the biosphere, which are increasingly scarce. In other words, the CE proposes the use of biodegradable materials in the manufacture of consumer goods in the manner of biological inputs. This is carried out in such a way that they can return to nature without causing environmental damage once their useful life ends. Based on this perspective, it is possible to reflect on the impacts generated by consumerism on the environment as a consequence of growing product waste, with the aggravating factor that these have an increasingly accelerated obsolescence (Baudrillard, 1970; Beck, 2005).

The methodology used consisted of a documentary review. The period of time for the collection of the information was from 1990 to 2020, when the main interdisciplinary documents on the economic-environmental problems on the planet were produced. Likewise, during this period, many interdisciplinary publications were produced on decolonization, reducing consumption, and the CE. The documentary base for this article included 59 texts. The following databases were used for the bibliographic search: Resh, Dice, In-Recs, Science Direct, LA Reference, Dialnet, Redalyc, Scielo, Base, Redib, Biologybrowser, Jurn, Erih Plus, Latindex, Scopus, Teseo, WOS and Google Scholar. BibExcel software was used for the semantic link co-occurrence relationships, and the Gephi program was used for the visualization of semantic communities.

Consequently, this text highlights the conceptual aspects found in the bibliographic review, which allowed a reflection on the contemporary crisis that involves a situation where the environmental crisis, the $\mathrm{CE}$, decolonization and reducing consumption interact. The information is presented as follows: first, the emerging guidelines of a $\mathrm{CE}$, linked to decolonization processes, as a strategy to mitigate the impact of human activity on the planet. In second place, the existing imbalances in the current economic system and the economic growth approaches that support it are analyzed. Later, as a third aspect, the approach of the CE is discussed as an alternative to solve some of the problems associated with the current model of the market economy. Finally, some relationships that are needed among consumption, the satisfaction of needs and the distribution of wealth. The three of them focused on reducing waste and the environmental impact of consumerism.

\section{Circular economy and decolonization processes}

It is important to mention, first, that the concept of $\mathrm{CE}$ has origins in different 
perspectives and theoretical frameworks, so it is difficult to trace it back to specific trend, it was the economist Kenneth Boulding in1966 who gave for the first time the idea of an economic model of circular flows (Scheel and Aguiñaga, 2017). Precisely, there is an absence of a defined concept for CE application in Latin America, since each initiative uses a different approach that lacks coherence and implementation may stagnate. Generally speaking, as mentioned (Suazo, 2017): Circular Economy (CE) is the strategic tool to face the issues in an economically viable way and besides a mechanism to establish new social dynamics and techniques which will lead to a responsible consume and production within a system that preserve and optimize the use of resources used in every process and each stage of material life. The circular economy examines new alternative development models that provide circular growth from the implementation of sustainable resources to the sharing economy. But, in terms of decolonial thinking, it implies redefining the conception of growth in pursuing the different benefits that can be offered to all the members of the community. This means that circular economy strategies are decisive for restructuring the takemake-dispose model through the active participation of all actors of supply chains and consumers.

To achieve this purpose, it is necessary to review the Western model of take-makedispose, and the negative effects caused by the current economic model based on "extract, transform, and disposing" and the consumer market trends threaten the stability of the economies and the integrity of natural ecosystems, which they are essential for human survival (Ghisellini, Cialani, and Ulgiati, 2016). From other postulates demarcated from economic growth, such as the decolonial approach which, as indicated by Zapata (2018), includes various practices, voices and movements, such as afro, indigenous communities, among others; are situated as transdisciplinary spaces that open up new epistemologies of knowledge beyond Western epistemic hierarchies. These are thoughts that are produced from local contexts: from historically subdued geopolitical identities and spaces, which now imagine and activate other ways of inhabiting the world.
This implies separating the nature of the different economic activities from the way that all ecosystem resources are consumed and their finiteness, with the aim of considering waste disposal and where to eliminate it or use it based on the design of the economic activity itself. It is a proposal that seeks an alternative and sustainable development, proposing different strategies throughout the supply chain, production and use and disposal of products and services so that each phase of the production value chain is thoroughly reviewed. This is expected to take place in order to reintroduce the maximum number of inputs, finished product, and waste to the same value chain to reduce environmental impact. But, to design a circular business model to Latin American companies they must fight poverty first, and then to implement management practices for value creation and examine in greater detail different perspectives, such as organizational culture, managerial commitment, digital technologies, external environment and the community of stakeholders (Centobelli, Cerchione, Chiaroni, DelVecchio, and Urbinati, 2020),

In the bibliographic review carried out, it was observed that, in general terms, since 2015 there has been a significant increase in the number of scientific investigations in indexed publications on the topic of Circular Economy (Schröder, Albaladejo, Ribas, MacEwen, and Tilkanen, 2020). The average growth has been $103 \%$ in the period dating from 2014 to 2018. China is the leader in this field, with $12.58 \%$ of total publications between 1995 and 2019, followed by England, Italy and Spain. Likewise, $40.26 \%$ of the investigations on $\mathrm{CE}$ are developed by four countries, three of which are European and one is from Asia. Latin America has a low international participation in scientific production on the subject: only Brazil is present in the list of the 25 countries with the highest production, with a total of 77 publications. Colombia ranks fourth with 11 registers, in Latin America, with 7.9\% participation (after Brazil, Mexico and Chile). These data confirm that European countries direct the theoretical basis of this economic trend.

It is clear that it is necessary to strengthen research on these issues and it becomes 
essential to activate the transition toward a new productive model that reduces pressure on the environment, and that is capable of transforming economic and social development focused on consumption and waste. Hence, a critical understanding of the Western way of life is necessary. One which, in terms of decolonial thinking, implies looking deeply at reality and the possibility of developing a pedagogy that harmonizes the being, knowledge and doing of man oriented towards preservation and conservation environmental care. In this regard, Cortina (2002) asserts it is necessary for "consumer groups to be aware that they are global citizens and that they must try to change the forms of consumption, personally and institutionally, for reasons of justice and happiness" (p. 266).

According to Betancourt and Zartha (2020), CE it represents an opportunity for Latin America because it could change the current economic diversity and at the same time to increase the employment rate, because it promotes a cyclical flow for the extraction, transformation, distribution, use, and recovery of materials and energy from products and services available on the market and ensures the use of resources repeatedly, thus preventing large amounts of resources from drifting and becoming waste. It represents a paradigm that aims to generate social equilibrium, protect the environment, and prevent pollution, thus facilitating sustainable alternative development. In terms of Tseng, Chiu, Liu and Jantaralolica (2020), the circular economy strategy comes from the regeneration of resources and must optimize environmental and resource sustainability within the closed-loop system in supply chains.

This proposal goes beyond the anthropocentric perspective and emphasizes the need to adopt another lifestyle in which the idea of happiness and personal fulfillment is separated from the idea of progress, which, in turn, is based on the consumption of goods that quickly become obsolete due to trends or technological advances (Cabrales, 2012). Hence, it goes beyond the 3Rs (Reduce, Reuse, Recycle), extending it to the 8Rs (Reflect, Reject, Reduce, Reuse, Recycle, Redistribute, Claim and Social Networks), applicable not only to entire product life cycles and design strategies, but also to the personal sphere in which purchasing decisions are made. Sustainable design strategies such as circular material flows from manufacturing systems and developments for that purpose (Lieder and Rashid, 2016), eco-efficiency (Huppes and Ishikawa, 2009) and cradle to cradle design (Braungart, McDonough, and Bollinger, 2007); are important because they make it easier for goods and services to be reintroduced into the system as biological or technical resources. In other words, they act as catalysts for the circular economy's operation.

Of course, initiatives of this type connect with decoloniality approach and gain strength in those communities where a lifestyle based on frugality and food autonomy is encouraged: one that is based on a direct relationship with the biosphere and that, consequently, establishes more efficient schemes for the use of natural resources. Let us remember this proposal the perspectives of the pre-Colombian American Indigenous communities who lived the day-to-day in the absence of the idea of accumulation and much less of the monetary wealth. In the words of Zapata (2018) "An axiom shared by these authors is that this decolonial turn or decolonization of knowledge, would come especially from everything that is exterior (or that is assumed exterior) to modernity and that has been disqualified by it" (p. 57). It should be clarified that "decolonization" corresponds to a return to ancestral roots and their lifestyles in harmony with nature; whereas "decolonization" (Chamberlain, 1997) refers to the historical process of political independence of a territory, with respect to a foreign State that dominates it, in a condition of political, social and economic dependence.

To this conception is added, among others, the Quechua concept of Good Living, or sumak kawsay, which refers to respect for "mother nature" and is based on a life structured in frugality, which is reflected in a greater awareness of the idea of using resources to fulfill basic needs, an authentically rational (moderate) consumption attitude. This implies the use of resources for the collective good, and waste reduction to lessen damages to the ecosystem. In the words of Choquejuanca (2011), "good living" posits the world's 
restoration and the balance between man and nature and it develops indigenous principles, codes, and values that have withstander and persisted for over five hundred years, which should be rescued in order to recover the culture of respect, life, and the promotion of harmony with nature.

Of course, initiating an abandonment of the hegemony of economic power in terms of Western principles, as suggested by decolonization, also integrating the environmental initiatives of the circular economy, leads to a review of the idea of economic growth and its consequences of social inequality. This will be the aspect that will be reviewed in the next section.

\section{A Contextualization of the Growth of Inequality}

In the early twentieth century, neoclassical theory would show supply and demand as the determining factors of price and market equilibrium, which determine the levels of production and income distribution in the former. With this social imaginary, the idea was generated that the buyer always tries to spend his money on those goods that provide him with the greatest possible utility according to his preferences (basket of preferences) and that as a result, his welfare is associated with the level of consumption he may reach. Furthermore, this was the frameworkfor the promotionand consolidation of the free market and the development of monopolies in the world. In turn, it led to the formation of finance capital, which was the platform based on which the relationships of dependency of the economically powerful countries on third-world countries that were weaker in economic and political terms were structured (Ray, 2003).

Seeing the environmental impact of these tenets, the 1990s welcomes renewed expectations, since it is possible to evidence that development is still unequal and poverty has further radicalized in many regions of the planet. In this context, Meadows and Randers (1972) and Brundtland (1987) propose a new look to measure growth, different from the traditional measures associated with Gross Domestic Product (GDP), a strictly economic indicator that manages to hide social inequalities. The former is considered so that the focus will no longer be on measuring the possession of money and goods but rather on evaluating the well-being of people, fulfilling their basic needs, and their actual opportunities, understood as "the conditions that facilitate access to education, health, and civil liberties" (Sen, 2000, p. 55). The foregoing, fortunately, ended up linking with the rights to education, health, a decent income, and a long life, resulting in the indicators that make up the HDI (Human Development Index), whose first report was published in 1990.

However, within the framework of the consumption levels of nations, there has been no representative progress in this respect. This happens since the increase in the levels of consumption in wealthy populations, which is what allows the constant accumulation of capital in the world, contrasts with the significant levels of poverty of a large part of the world's population (also associated with their unmet basic needs) and with an enormous environmental deterioration. In short, the inequality gaps in income and in the distribution of goods and resources in the world (including those extracted from nature) have continued to widen. Piketty's research (2014) shows a disproportionate growth in inequality after the 1970s, when neoliberal policies began to permeate the minds of most of the rulers of developed countries and some Latin American ones, starting with Chile.

Therefore, the need to stop considering economic growth as a synonym of well-being becomes evident and focus on promoting sustainable consumption that does not deplete and destroy the natural resources of the biosphere in favor of consumer satisfaction in developed countries. "The earth's ability to sustain life, and therefore economic activity, is threatened by the way we extract, process, transport, and dispose of a vast flow of resources - some 220 billion tons a year, or more than 20 times the average American's body weight every day" (Hawken, Lovins, and Lovins, 2007, p. 2).

This is clearly seen in the consumption levels in the country analysis; according to World Bank data, in 2019, the final household consumption expenditure for high-income countries was fifty-five (55) times higher 
than for low-income countries and, compared to Latin America, it was four times higher (World Bank, 2019).

On the other hand, a similar situation is shown for individuals, as suggested by Oxfam (2018):

The richest $1 \%$ of the world's population accounted for $82 \%$ of the wealth generated the previous year, while the poorest half did not benefit at all. In that same year, the richest $1 \%$ of the planet owned $48 \%$ of the world's wealth. Yet, the trends are worsening: in 2019, that $1 \%$ would own more than $54 \%$. If we were to break down the large segments, we would find even more irritating asymmetries: the eighty richest people on the planet currently own the same as the 3.6 billion poorest. In this scandalous context, Latin America's outlook, in spite of having improved in the last decade, still has some very concerning features (p. 11).

From here comes the importance of recognizing that currently there is "a growing global concern to significantly reduce the negative environmental impacts that put life on the planet at serious risk" (Pinzón and Echeverri, 2012, p. 132). And, regarding this outlook, several proposals which have been developed in terms of sustainable development at different scales arise, giving predominance to those that emerge from the peoples of the south and revolve around the analysis and understanding of the different relationships that "operate within cities, and of these with their immediate surroundings, as a system to which the greatest responsibilities are associated in terms of services and impact on the environmental capacity of the territory" (Pinzón and Echeverri, 2012, p. 132).

In this regard, when thinking about environmental sustainability based on a decolonial perspective and in terms of harmonizing being, knowing, and doing, it gives particular importance to considering and conceiving all urban spaces as a whole that connects with and depends on the nearby contexts - rural areas - and those more remote - jungle, moors, and other ecosystems - since in many cases - if not all - it becomes an essential aspect that enables understanding and analyzing the different dynamics that occur in the territory.
From the previous point of view, which questions the real possibilities of equitable growth to generate equality and social equity, then it is convenient to explore the alternative suggested by the authors analyzed, aims to gradually decouple growth from the consumption of finite resources, and development of a reduction consumption, in the environment of the $\mathrm{CE}$; scheme that would move humans away from a transgressive market economy of ecosystems. This matter will be discussed in the next section.

\section{Circular economy and consumption reduction as an alternative to market economy}

In accordance with Escobar (2005a) the decolonial perspective is a different way of thinking, which goes against the great modernist narratives -Christianity, liberalism and Marxism-, and that locates its questions on the edges of thought systems (in frontier thoughts) opening the possibility of non-Western modes of thought and epistemological frameworks. Is clear that humanity is at the crossroads of rethinking their current economic model, anchored in neoclassical tenets originated in Europe and north America in the XX century, that would be developed by neoliberalism, which has led to excessive consumption. So, the decolonial approach lay the foundations to migrate to alternative models that relativize the market's internal force as the only choice to find wellbeing. This is also understood by Barkin (1998) when he asserts that "A free market strategy cannot bridge the gap between the rich and the poor, which is characteristic of the dualisms of our times. Rather, we propose an approach that recognizes that natural resources are limited" (p. 2). Piketty (2014) also focuses on this same train of thought:

Accumulation stops at a finite point, but that point can be extremely high and destabilizing. We will see that the enormous increase in the total value of private wealth observed since the 1970s-1980s in rich countries as a whole is a direct result of this logic (p. 24).

As evidenced, the uncontrolled exploitation of natural resources, justified by the inherent dynamics of free supply and demand, does 
not outline an ecological path that allows the equitable distribution of wealth and available goods. Neither does a more harmonious relationship with the environment, understanding that "biophysical foundations and ecology itself teach us that man does not use natural resources in isolation, but uses ecosystems comprehensively" (Aguilera and Alcantara, 1994, p. 19).

In this sense, the decolonial concern goes beyond an exclusively economic perspective and encompasses social environmental representations originated in certain postulates of Latin American origin, that recognize that there are profound implications between the survival and general well-being of all human beings and the conditions of the biosphere. Hence, a decolonial ecological perspective is configured as biocentric and separated from anthropocentric interests. That is why, based on this configuration, it is also necessary to posit other development options that gather the alternative emerging ideals on progress and wealth and that break with the idea of western growthconsumption focused on the market and on the growth of aggregate demand as the only route (Cabrales, 2012).

However, as the world economy was structured in globalized market whose rituals are shaped around international trade and are based on the ideal of happiness that comes from consuming, the consideration of these new perspectives on consumption cannot depend on governments or local politicians. Changes in consumption habits must be based on the joint wills of conscientious global citizens instead, with the possibilities generated by their connection through collectives and social networks, but always in the context of their specific cultural and regional environments.

The results of orthodox economic practices increasingly show the flaws of the globalized consumer economic system. In the words of Ray (2003): "with low incomes being unequally distributed, the consequences for poverty, malnutrition, and the mere waste of human life are literally unimaginable" (p.189). It is clear then, when looking at the tenet of the representatives of neoclassical economy (resulting in neoliberal), that the free operation between supply and demand does not achieve any equitable redistribution of wealth (Piketty, 2014) and drives consumer society.

Based on these views, although it may seem a diatribe against the theorists of the current economic models, it is considered necessary to make evident four issues that can shed light for future actions: a) In a world where human labor is increasingly replaced by machines (Gorz, 1995; Rifkin, 2004) the idea that consumption is directly linked to employment collapses, more so if we consider that currently monetary resources for consumption are achieved more through the movement of capital than through labor itself (material and precarious work in most poor countries). b) A high percentage of the products that are consumed in developed countries are those that require the rawest materials and precarious work in the third world and, in turn, are used to serve a small number of consumers who are the ones that generate the most waste and the most they pollute. c) The market economy was never able to regulate the exploitation and use of natural resources through supply and demand and through price regulations.

In sum, these factors indicate that the market economy has not really led to an improvement in wealth distribution in conditions of employment and well-being of all citizens, nor in their possibilities of improving their quality of life. They have shown that the benefits it promises only reach a minority group of the population because production only satisfies specific segments of high-income consumers.

In this scenario, the need to think about $\mathrm{CE}$ as a life choice whose idea of progress is not centered on consumption and waste or on the individual and immediate satisfaction of the desire for pleasure and power. Hence, we purpose conscientiously reducing consumption, reflecting or rejecting before purchasing, repairing, and reusing, recycling and reincorporating waste into production value chains and finally, resistance, so that the exploitation of resources can be reduced, the destruction of ecosystems halted, and the global redistribution of goods (and wealth) carried out as a function of fulfilling the basic needs of the entire population, ultimately applying the 8Rs. 
This life option, as Márquez (2020) points out:

Focuses on the understanding that the current economic model, applied in most of the countries of the planet, forgot the health of the ecosystem. Therefore, the growing environmental deterioration is observed as a consequence of the anthropic interventions in the ecosystems, aimed at the extraction of natural resources, from which comes, what might be called, the wealth of nations (p. 8).

According to Martínez (1997), this implies a process of democratic and equitable transition toward a CE, orienting human labor toward reforestation and care of forests and oceans, reducing the production of polluting goods and less luxury consumption, in which environmental sustainability, recovery, recycling, reuse, and repair. In this same line, Latouche (2010) suggests rethinking the concept of well-being and wealth currently generated by classical capitalism, to undertake the tenet of degrowth and the idea of happiness based on sobriety and frugality. Regarding the latter he asserts:

The values on which growth and development, and especially progress rest, do not correspond at all with deep universal aspirations. These values (conception of time, relationships with nature, etc.) are related to Western history, and do not likely hold any meaning for other societies. Where there are no myths to substantiate the claim for a rational control of nature and faith in progress, the idea of development and growth is meaningless and the practices related to it are totally impossible because they are unthinkable and forbidden (p. 34).

Within this framework, the proposal of reducing consumption that recovers the idea of frugality, sobriety, moderation, fulfillment of basic needs and an equilibrium between man and nature, based on a CE, seems to be relevant for today's society during the environmental crisis derived from climate change. These particularities are outlined in the following section.

\section{Consumption, fulfillment of needs, and wealth distribution}

In this context, it is necessary to refer to the relationship between consumption, fulfilling needs, and the distribution of wealth. In terms of this relationship, García Canclini (1999) indicates that there is, on the one hand, a naturalistic conception of needs in which these are considered to be socially constructed (even the most elementary biological needs are fulfilled differently in different cultures and at different historical moments). On the other hand, the instrumentalist conception of goods, which assumes that goods only have one use value insofar as they all fulfill concrete needs; within this framework, each of these perspectives result in a specific way of understanding consumption.

In this sense, it should be understood that consumption goes beyond this simple relationship and that it involves the sentimental, spiritual, and symbolic dimensions of the human being; this is how García Canclini (1999) also interprets it, asserting that consumption is nothing more than "the set of processes of appropriation and use of products in which the symbolic value prevails over the values of use and change, or where at least the latter are configured as subordinate to the symbolic dimension" (p. 6). Following this train of thought, Simmel (1907) asserts that value is never an inherent property of objects, but rather a judgment about them issued by subjects. Baudrillard (1970), on his part, attributes to consumption an ideological condition insofar as he asserts that in the "system of objects" there is an ideological framework in which expiration, obsolescence, and novelty reign. In this respect, binding obsessions appear such as the principle of personification (understood as that form of individualizing mass-produced articles) or novel ethics of infinite credit and non-productive accumulation.

Specifically, already regarding this idea of needs understood as a social, cultural, and historical construction, so that consumption is seen as a mechanism of human and social fulfillment, it can be observed how the final value of many mass consumption products manufactured in China, for example, is not an actual added value in its final value (since this is only apparent), given that its price is more associated to the brand than to its production cost (which are relatively low in the case of Southeast Asia). Thus, the possibility of fulfilling the human needs and their symbolic fulfillment is limited; these 
types of facts are what would be steadily increasing the income of the owners of the brand or the patent, but never allowing the improvement of salaries, living conditions, and worker well-being that manufacture them or the countries that intervene in their manufacture.

This also implies that, in the neoliberal model, in which low salaries predominate in the lower strata and human labor is replaced by technology, the level of consumption is actually concentrated in a few people and is no longer associated with the level of existing employment nor with its remuneration. This happens since the cost of human labor in the production of material goods is less and less representative of total costs.

On the other hand, under the schemes of current globalization and the establishment of wild capitalism, in terms of Harvey (2005), capital accumulation is no longer based only on the classic mechanism of extracting the surplus value of labor, but on processes of unbridled extraction from nature, which is seen simply as an ever-available deposit of natural resources, as if these were inexhaustible. This scenario also combines with the overexploitation, at a global level, of millions of economically subjugated workers and with the plundering of the wealth of communities by financial agents or the State itself. Regarding this idea, Harvey (2005) asserts that "capital, which does not reproduce either its labor force or its natural resources, rushes toward speculative financial schemes which, in addition to the crisis of its accumulation system, provokes a series of social and ecological crises" (p. 4).

The foregoing indicates that the human being, by force of capitalism, is separated from his most inherent vocation or, in other words, from the direct relationship with nature and with the means of production of self-sustainability, basic principles of indigenous ancestral knowledge that from the decolonial perspective gain relevance in today's world. Therefore, under the rituals of the market economy, consumption has gone from being a basic and symbolic exercise of fulfilling typical human needs, to a dynamic of a forced exchange of goods and services that do not respond to actual needs and that. In addition, foster exclusion practices, since the immense majority of the population does not have real possibilities to access the consumption of products that the globalized market establishes as a requirement (although only in appearance) to achieve happiness and a decent life.

The current pattern of world power consists on the articulation between capitalism as a universal pattern of control of labor and social exploitation, the nation-state / modernas a central and hegemonic form of control of collective authority, the Eurocentrism as a hegemonic form of control of subjectivity / intersubjectivity and the production of knowledge (Quijano, 2000).

Similarly, Polanyi (2012) had already stated that the market economy is nothing more than an institutionalized process through which the material needs of the individual in society are fulfilled and that therefore the phenomenon of consumerism responds to culturally created principles of action that end up giving rise to socialized actions. It is in this scenario that human beings work, buy, sell, dispose of their possessions and carry out the transactions that give rise to the consumerist scenario in the market. This position allows us to understand that these behaviors are artificial and that they are culturally conditioned by the institutions that substantiate the idea of the market that has been so defended (Estermann, 2014; Lander, 2000).

Based on this we can conclude that the current individualistic consumerist behavior is based on an artificial reality that is culturally reinforced by economic institutions and created by a mercantile system that sells the idea that utilitarian morality is natural in man and that it prevails in his decisionmaking process. On this, the decolonial approach shows that there are alternative ways created from the south of organizing the exchange of goods and services, different from frenetic individualistic consumerism that aims at generating status (Gentili, 2019).

Along the same lines, Coraggio (2015) states that the economic agents of nations see consumption as the driver of economic growth, both through State spending and through the injection of resources at the base of the income pyramid. 
Since the utilitarian perspective is that individual well-being is based on greater consumption, although there is no risk of consumerism for the poor, there is an "upward spill" generated by these policies that leads to an exacerbation of consumerism. In every case it is confirmed that the commercial, financial, and industrial sectors and the media in general have strongly increased their profits and income as a result of the application of this model (Coraggio, 2015, p. 19).

Thus, broadening the base of potential consumers is always a priority in the plans of the governments in power; this is so much so that even economic incentives and subsidies are included in government policies with the ultimate goal of improving the consumption conditions of the population and not as a means to reduce inequality or extreme poverty levels.

That is why, based on Polanyi (2012), it is possible to propose the possibility of exploring economic practices different from the one currently promoted in a hegemonic way, since they have accompanied human beings, in an empirical way, throughout history, and are based on forms of integration, association, and cooperation (among which are reciprocity, redistribution, or exchange) and not on structures of individualism, disjunction, and competitiveness. These other economic forms, such as the concept of Good Living, CE, reducing consumption, could configure the recycling, repair, and reuse of goods in a society, but with the added value that they maintain the cultural imprint of those who produce the articles of exchange. Of course, these dynamics move away from the artificiality of the open market scenarios of the 21st century and always find in the monetary systems of nations all kinds of obstacles and hindrances.

Finally, the circular economy and reducing consumption practice allows deploying policies in which individuals participate in a more direct and committed manner in their leading role in the conservation of the environment and sustainability, based on broad education and training policies that generalize new ways of undertaking the citizenship (Mulder, 2020; Rincón, 2015).

Thus, the aforementioned route offers the possibility of understanding that there are no convincing connections that lead us to think that mass consumption, under the cultural conditions of the globalized market, corresponds to natural human behaviors that cannot be avoided in the modern world or that show unequivocally a greater benefit for all society.

As Bauman (2009) indicates, in a market society, money changes hands at multiple times and everything becomes more liquid. Nations and States can no longer decide the direction of capital flows. Global capital flows and travels without control. Therefore, businesses and companies placed at the service of the consumer, today have been placed at the service of capital itself, falsifying its function of being at the service of human progress.

\section{Conclusions}

This scenario shows the need for nations to define an economic policy and system based on a circular economy that serves the comprehensive management of biodiversity. One that aims for the protection, management, and sustainable use of ecosystems. This also includes the control of deforestation to be linked to the comprehensive management of water resources and the processes of adaptation to climate change.

Based on the review conducted, it is possible to deduce that the neoclassical vision of the economy that has been irrigated throughout the 20th century finds serious difficulties in explaining the reasons for the repeated phenomena of unemployment, depression, economic downturn, and depredation of biodiversity. Thus, the focus anchored in the free supply and demand of products and services, which had been shown to be the expeditious way to consolidate markets, to achieve development, and full employment, has encountered serious hindrances to achieve its social imaginary across the planet.

Meanwhile, companies have concentrated their marketing strength on the dynamics of consumption and have built a myth around the customer (the final consumer or service user), who ends up being the object of aggressive campaigns to incite consumption (Escobar, 2005a). However, in spite of these efforts, 
domestic economies, have not had positive results such as the failure to eradicate poverty, growing unemployment, increasing social inequality, the specific accumulation of wealth, and the concentration of consumption possibilities in privileged segments of society.

These initiatives to implement the 8Rs and to consume responsibly, considering the balance of nature and with care for the human being himself, are showing the outlines of a moderate, associative, solidarity-based economy that protects the environment. Opening people's mind and creating awareness about the existing issues is a first step but it requires that we all understand the implications of each act of consumption. In this sense, Schröder (2020) warns that "An approach based on social innovation for the circular economy in the Latin American and Caribbean region can reduce poverty, promote human development and promote sustainable consumption patterns, in favor of a more resilient and inclusive society "(p. 62).

Quijano (2000) affirms that the power structure was and even continues to be organized in and around the colonial axis, therefore, the market economy model, inspired by the Western center of power, essentially determines the consumerist paths of the contemporary societies. Of course, these reflections do not mean the elimination of consumption, since this is impossible, given that societies will always require products and services for their subsistence, instead what a CE proposes is a call to combine the equitable fulfillment of the needs of all human beings (in a fair proportion) rejecting invasive industrial processes and those activities that destroy pristine ecosystems.

The decolonial perspective also aims at generating a theoretical approach to ancestral tenets of the peoples of the south that vindicates subjects, human groups and their culture. A method that recognizes the needs of the populations at a global level and the inherent conditions of the context and each one's historical moment; that implies an approach in which the human being sees himself immersed and integrated in ecological dynamics and not as an observer or external actor.

The CE is an alternative that seeks to redefine the concept of growth, with the purpose of redesigning the relationship between humans and ecosystems. This leads to dissolving the economy of the consumption of finite resources, towards a scheme that eliminates waste from the design of the products. This model requires renewable sources of energy, based on three actions: eliminating waste and pollution from the design, sustaining products with prolonged uses and regenerating natural systems, that is, exchanging the typical cycle of manufacturing, use and disposal of resources, in favor of the greatest possible reuse and recycling (Polanyi, 2012).

In this line of thought, the philosophical bases of a circular economy have been gathered around these purposes: 1. Prepare human beings to become more and more aware of their purchasing decisions, which implies that they think more and more about their true needs. 2. Reconvert companies and supply chains so that they, creatively, adapt to production lines that mitigate the environmental impact via waste and on natural resources; in this case their basic mission would be to reuse and recycle in all phases of the production value chain from the perspective of responsible management (Carroll and Laash, 2020). 3. Promote local and regional markets that encourage reflection, recovery, reuse, recycling, repair, and rejection; in this situation goods and products should have long circulation cycles in the economy which would significantly reduce solid waste. 4 . Promote the practice of reducing consumption as a normal event in society, and not as different or atypical; with this, the era of the consumer man would close a period of great uncertainty where happiness was confused with possessing and treasuring to give way to the era in which it is more associated with the growth of those human attributes or dimensions that are more transcendent and spiritual. 5. Drastically increase the productivity of natural resources and from deep reflection, reducing the wasteful and destructive flow of resources from depletion to pollution, and finally think about what the limit of human needs is and what we really need to live.

\section{Conflict of interest}

The authors declare no conflict of interest. 


\section{Source of Financing}

This research is sponsored by Universidad Militar Nueva Granada, and performed by Cultura y Desarrollo Humano Group researchers and staff.

\section{References}

Aguilera, F., y Alcántara, V. (Comp.) (1994). De la economía ambiental a la economía ecológica. Icaria.

Banco Mundial (2 de febrero de 2019). Indicadores economía mundial por sectores. http://datos. bancomundial.org/indicador

Baudrillard, J. (1970). La sociedad de consumo. Sus mitos, sus estructuras. Plaza y Janés.

Bauman, Z. (2009). La vida de consumo. FCE.

Bajoit, G., Houtart, F., y Duterme, B. (2009). América Latina ¿un giro a la izquierda? Editorial Laboratorio Educativo.

Barkin, D. (1998). Riqueza, pobreza y desarrollo sustentable. Editorial Jus.

Beck, M. B. (2005). Environmental foresight and structural change. Environmental Modelling and Software, 20(6), 651-670. https://doi. org/10.1016/j.envsoft.2004.04.005

Bernstein, S. (1973). Teoría de la descolonización. Porrúa.

Betancourt, C. M,. \& Zartha J. W. (2020). Circular economy in Latin America: A systematic literature Business Strategy and the Environment, 29(6), 2479-2497. https://doi. org/10.1002/bse.2515

Braungart, M., McDonough, W., \& Bollinger, A. (2007). Cradle-to-cradle design: Creating healthy emissions-A strategy for eco-effective product and system design. Journal of Cleaner Production,15(13-14), 1337-1348. https://doi. org/10.1016/j.jclepro.2006.08.003

Brundtland, G. (1987). Our Common Future. Oxford University Press.

Cabrales, O. (2012). La aceleración del tiempo en relación con la idea de progreso y la crisis del trabajo. Entramado, 8(2), 106-122. https:// revistas.unilibre.edu.co/index.php/entramado/ article/view/3431

Cabrales, O., y Márquez, F. (2016). El buen vivir y el no consumo como modelos de desarrollo desde la perspectiva de la bioética global.
Revista Latinoamericana de Bioética, 17(1), 168183. http://dx.doi.org/10.18359/rlbi.1726

Carroll A. B., \& Laash, O. (2020). From Managerial Responsibility to CSR and Back to Responsible Management (pp. 84-90). In O. Laasch, D. Jamali, R. E. Freeman, \& R. Suddaby (Eds.), The Research Handbook of Responsible Management. Cheltenham: Edward Elgar.

Castro, S. (2007). Decolonizar la universidad. La hybris del punto cero y el diálogo de saberes (pp. 79-91). En S. Castro-Gómez y R. Grosfoguel (Eds.), El giro decolonial: reflexiones para una diversidad epistémica más allá del capitalismo global. Siglo del Hombre Editores.

Centobelli, P., Cerchione, R., Chiaroni, D., Del Vecchio, P., \& Urbinati, A.(2020). Designing business models in circular economy: A systematic literature review and research agenda. Business Strategy and the Environment, 29(4). https://doi.org/10.1002/bse.2466

Choquehuanca, D. (2011). Vivir Bien. Diplomacia para la Vida. Ministerio de Relaciones Exteriores.

Coraggio, J. (2015). Para pensar las nuevas economías: conceptos y experiencias en América Latina. Instituto de altos Estudios.

Cortina, A. (2002). Por una ética del consumo: La ciudadanía del consumidor en un mundo global. Taurus.

Chamberlain, M. E. (1997). La descolonización. Ariel.

Díaz Pérez, V. R. (2017). El pensamiento decolonial: una apuesta hacia los saberes ancestrales para la construcción de la identidad latinoamericana. Actualidades Pedagógicas, (70), 125-145.https:/l doi.org/10.19052/ap.4177

Escobar, A. (2005a). El postdesarrollo como concepto y práctica social (pp. 17-31). En D. Mato (Coord.), Políticas de economía, ambiente y sociedad en tiempos de globalización. Facultad de Ciencias Económicas y Sociales, Universidad Central de Venezuela.

Escobar, A. (2005b). Más allá del Tercer Mundo. Globalización y diferencia. Instituto Colombiano de Antropología e Historia.

Estermann,J. (2014). Colonialidad, descolonización e interculturalidad. Polis, 38. https://journals. openedition.org/polis/10164.

García Canclini, N. (1999). El consumo cultural: una propuesta teórica (pp. 26-49). En G. Sunkel (Coord.), El Consumo Cultural en América Latina. Convenio Andrés Bello. 
Ghisellini, P., Cialani, C., \& Ulgiati, S. (2016). A review on circular economy: the expected transition to a balanced interplay of environmental and economic systems. Journal of Cleaner Production, 114(15), 11-32. https:// doi.org/10.1016/j.jclepro.2015.09.007

Gentili, P. (2019). Antología del Pensamiento Social Latinoamericano y Caribeño. CLACSO.

Gorz, A. (1995). Metamorfosis del trabajo. Búsqueda de sentido. Crítica de la razón económica. Sistema.

Harvey, D. (2005). El nuevo imperialismo: acumulación por desposesión (pp. 99-129). En L. Panitch, y C. Leys (Eds.), El nuevo desafío imperial - Socialist Register 2004. CLACSO.

Harvey, D. (2008). El Neoliberalismo como destrucción creativa. Apuntes del CENES, 27(45), 10-34. https://dialnet.unirioja.es/servlet/ articulo?codigo $=4949778$

Huppes, G., \& Ishikawa, M. (2009). Ecoefficiency guiding micro-level actions towards sustainability: Ten basic steps for analysis. Ecological Economics, 68(6), 1687-1700. https:// doi.org/10.1016/j.ecolecon.2009.01.007

Lander, E. (Comp.). (2000). La colonialidad del saber: Eurocentrismo y ciencias sociales. CLACSO-UNESCO.

Latouche, S. (2010). Pequeño tratado del decrecimiento sereno. Icaria.

Lieder, M., \& Rashid, A. (2016). Towards circular economy implementation: A comprehensive review in context of manufacturing industry. Journal of Cleaner Production, (115), 36-51. https://doi.org/10.1016/j.jclepro.2015.12.042

Hawken, P., Lovins, A., \& Lovins, L. H. (2007). A Road Map for Natural Capitalism. Operations management. Harvard Business Review. https://hbr. org/2007/07/a-road-map-for-natural-capitalism

Márquez, F. (2020). Hacia una fundamentación de la bioética ambiental desde la visión de Fritz Jahr, Aldo Leopold y Van Rensselaer Potter. Revista Colombiana de Bioética, 15(2), 1-26. https://doi.org/10.18270/rcb.v15i2.3009

Martínez, A. (1997). Deuda ecológica y Deuda externa. Ecología Política, (14), 157-173. Fundación ENT. https://www.jstor.org/ stable/20742951

Martínez, L., Henríquez, A., y Freire, N. (2019). Economía circular y políticas públicas: Estado del arte y desafíos para la construcción de un marco político de promoción de economía circular en América Latina. Fundación KonradAdenauer-Stiftung e.V. (KAS), Programa Regional Seguridad Energética y Cambio Climático en América Latina (EKLA), Centro de Innovación y Economía Circular (CIEC). https:// www.kas.de/documents/273477/273526/m\%C3 $\% \mathrm{ADa}+\mathrm{Circular}+\mathrm{y}+\mathrm{Pol} \% \mathrm{C} 3 \%$ ADticas $+\mathrm{P} \% \mathrm{C} 3 \%$ BAblicas.pdf/e7d98c0f-423c-947c-fe3e-6a83ae $\underline{5 f b 7 c 3 ? \text { version }=1.1 \& \mathrm{t}=1580245377248}$

Meadows, D., y Randers, J. (1972). Los límites del crecimiento. Taurus.

Mignolo, W. (2005). El Pensamiento des-colonial, desprendimiento y apertura: un manifiesto. RevistadelInstitutoInterdisciplinariodeEstudios Latinoamericanos, 5(6), 7-38. https://dialnet. unirioja.es/servlet/articulo?codigo $=5468282$

Mulder, N., y Albaladejo M. (Coords.). (2020). El comercio internacional y la economía circular en América Latina y el Caribe (Comercio Internacional, $\mathrm{N}^{\circ}$ 159). Comisión Económica para América Latina y el Caribe [CEPAL]. https://repositorio.cepal.org/bitstream/ handle/11362/46618/1/S2000783 es.pdf

Oxford Committee for Famine Relief OXFAM (2018). Premiar el trabajo, no la riqueza. https://oxfam.app.box.com/s/ eosi27xj7nxuyywysr06d734ct1xyuev/ file/267209868741

Piketty, T. (2014). Capitalism in the Twenty-First Century. Harvard University Press.

Pinzón, M. V., y Echeverri, I. C (2012). La sostenibilidad ambiental regional: una propuesta metodológica para su estudio más allá de la ecología urbana. Revista Luna Azul, (34), 131-147.

Programa de las Naciones Unidas para el Desarrollo [PNUD] (2015). Panorama general. Informe sobre Desarrollo Humano 2015. Trabajo al servicio del desarrollo humano. http://hdr. undp.org/sites/default/files/2015 human development_report_overview_-es.pdf.

Polanyi, K. (2012). El lugar de las economías en las sociedades y La economía como proceso instituido. En J. L. Laville (Edi.), Textos escogidos. CLACSO, UNGS.

Quijano, A. (2000). Colonialidad del poder: Cultura y conocimiento en América Latina (pp. 117-131). En W. Mignolo (Comp.), Capitalismo y geopolítica del conocimiento: El eurocentrismo y la filosofía de la liberación en el debate intelectual contemporáneo. Ediciones del Signo.

Quijano, A. (2007). Coloniality and Modernity/ Rationality. Cultural Studies, 21(2-3): 168-178. https://doi.org/10.1080/09502380601164353 
Ray, D. (2003). Economía del desarrollo. Princeton University Press.

Rifkin, J. (2004). El Fin del Trabajo. Paidós.

Rincón, O., Millán, K., y Rincón, O. (2015). El asunto decolonial: Conceptos y debates. Perspectivas. Revista de Historia, Geografía, Arte y Cultura, 3(5), 75-95. http://biblioteca.clacso.edu.ar/ Venezuela/ceshc-unermb/20170219052712/ RPS45.pdf

Sen, A. (2000). Desarrollo y libertad. Planeta.

Simmel, G. (1978). Filosofía del Dinero (R. García Cotarelo Trad.). Instituto de Estudios Políticos. (Obra original publicada en 1907).

Scheel, C., y Aguiñaga, E. (2017). La Economía Circular, una alternativa a los límites del crecimiento lineal (2 ${ }^{\mathrm{a}}$ ed., pp.157-171). En E. Raufflet, L. P. Derbez, C. G. de la Torre, y J.F. L. Aguilar (Eds.), Responsabilidad, ética y sostenibilidad empresarial. Pearson. https://doi. org/10.1306/09251211152
Schröder, P., Albaladejo, M., Alonso Ribas, P., MacEwen, M, y Tilkanen, J. (2020). La economía circular en América Latina y el Caribe. Oportunidades para fomentar la resiliencia. Real Instituto de Asuntos Internacionales Chatham House. Programa de Energía, medio ambiente y recursos. https://www.chathamhouse.org/ sites/default/files/2021-01/2021-01-13-spanishcircular-economy-schroder-et-al.pdf

Suazo, B. (2017). Economía Circular en Chile: Alcances, problemas y desafíos en la gestión de la ley REP.24. http://repositorio.uchile.cl/ handle/2250/146815?show=full

Tseng, M.L., Chiu, A., Liu, G., \& Jantaralolica, T. (2020). Circular economy enables sustainable consumption and production in multi-level supply chain system. Resources, Conservation and Recycling, 154, 104601. https://doi. org/10.1016/j.resconrec.2019.104601

Zapata, C. (2018). El giro decolonial. Consideraciones críticas desde América Latina. Pléyade (Santiago), (21), 49-71. https://dx.doi. org/10.4067/S0719-36962018000100049

\footnotetext{
How to cite this paper?

Cabrales Salazar, O., Márquez Vargas, F., \& Garzón Pascagaza E. J. (2021). Circular economy and reducing consumption from a decolonial approach. Cuadernos de Administración, 37(70), e5110905. https://doi.org/10.25100/cdea.v37i70.10905
}

Cuadernos de Administraciónjournal by Universidad del Valle is under licence Creative Commons ReconocimientoNoComercial-SinObrasDerivadas 4.0. Based in http://cuadernosdeadministracion.univalle.edu.co/ 